\title{
Molecular Tools in Buffalo's Characterization: Practical Applications. A Review
}

\author{
Odalys Uffo Reinosa* and Atzel Acosta Abad
}

\begin{abstract}
Centro Nacional de Sanidad Agropecuaria (CENSA), Laboratorio Genética Molecular (GenMol), CENLAC. Mail Box 10, CP 32700, San José de las Lajas, Mayabeque, Cuba
\end{abstract}

\begin{abstract}
The utility of the techniques of analysis concerning DNA is clear and a review of the main applications of the molecular tools in the genetic characterization of buffalo populations is done.
\end{abstract}

Keywords: Buffaloes, molecular markers, polymorphism, DNA, genetic.

In the last six to seven decades has taken place an accelerated development of the applications of the molecular genetics in the evaluation of the hereditary characters and in the animal identification. In the same way, in the field of the animal genetic it has happened a true revolution in all the slopes of the investigation, related to the quality of production and the improvement of the animal groups, with the confluence of so different specialties but so related as quantitative genetic, cytogenetic, biochemical genetic, molecular biology, and the calls "omics sciences", as genomic, proteomic, metabolomic, as well as the bioinformatic, that provide useful tools for the studies of genetic polymorphism.

One of the mostly accepted definitions of genetic polymorphism is that one relates to the occurrence in a population of discontinuous variants of genetic origin, with a frequency of the gene that cannot be explained by the exclusive action of the recurrent mutation, for being this extremely rare event [1]. Several types of polymorphisms exist and can be classified in morphologic, biochemical, chromosomal and molecular, in dependency of the level at which the variation is analyzed [2].

The studies of genetic variability are based on the identification of the genic variation, attribute that cannot be exhaustive measured because it is impossible to examine each gene in each individual of a given species to obtain a complete inventory of the variability of the species at issue. Normally a representative sample is taken from a population, through which it is possible to consider his genetic variability, using a character or marker that causes the measurement of this variability.

*Address corresponding to this author at the Centro Nacional de Sanidad Agropecuaria (CENSA), Laboratorio Genética Molecular (GenMol), CENLAC. Mail Box 10, CP 32700, San José de las Lajas, Mayabeque, Cuba; Tel: 0053-47863014; Fax: 0053-47861104; E-mail: uffo@censa.edu.cu
The molecular markers can be associated to any phenotypic difference genetically controlled and used in genetic analyses. Also they can be used to differentiate groups of individuals.

In the 60's markers associated to morphologic characters were discovered, followed by the biochemical markers (isoenzymes and antigens). With the discovery of enzymes of restriction or endonucleases [3], the analysis concerning DNA became possible, which was accelerated vertiginously with the appearance of the polymerase chain reaction (PCR) that allows the test-tube amplification of the DNA molecule for its later study [4]. In parallel, the development of the cloning techniques and DNA sequencing made possible a fast accumulation of information about the eukaryotic genomes with the discovery of several classes of sequences and other molecular markers.

Ideal markers for the determinations of genetic variability are those that: have the capacity to detect high levels of polymorphism; have high heritability that allows to accede to all the regions of the genome; are independent of the physical, healthy and developmental state of the animal; will be easy to obtain and to detect through cheap methods; are considered not depend on the environmental conditions; have the capacity to detect as silent mutations as those that originate amino acids changes; and that their obtaining is possible from any type of sample (any cell that contains nucleus) [5].

The molecular markers for the characterization of cattle populations of commercial interest have been used widely, basically in bovine, sheep and goat; in the last time, these applications to the study of buffaloes populations have been increased with different objectives between which it is possible to mention the population characterization, the study of associated 
genes to productive characters, the attended reproduction, studies of traceability of commercial products originated from buffaloes meat or milk, as well as biodiversity studies.

One of the main applications of the characterization of domestic populations is related to the conservation of the breeds or species that are in extinction danger. In many occasions these populations contain unique combinations of genes that have allowed them to survive and to adapt to very aggressive conditions. In such sense have being favored the study for the maintenance of species that genetically can resist to changes of the environment or the threats of emergent diseases and that responds to the nutritional needs of the human population or the social or trade conditions.

An example of this is the study realized by Maués Albuquerque et al. [6] who used RAPD markers (Random Amplified Polimorphic DNA), to characterize two genetic groups of buffalo, Carabao and Baio, which are being in situ conserved, as well as to verify the genetic relationship among them and to other three genetic groups of buffalos raised in Brazil, considered commercial breeds: Murrah, Jaffarabadi and Mediterranean. There were used 21 polymorphic primers that produced 98 markers. Genetic variability within and between groups was estimated in 26.5 and $73.5 \%$, respectively, suggesting significant divergence among groups. On the analysis between pairs of groups, the divergence was about 40 and 18\%, respectively, when the Carabao $x$ Mediterranean and the Murrah $x$ Jaffarabadi were compared. The estimated genetic divergence between Baio and Murrah groups was $20.42 \%$, indicating that they are distinct groups. The five genetic groups are genetically distinct, indicating the need to conserves the Carabao and Baio, two genetic groups in danger of extinction in Brazil. In addition the authors concluded that RAPD markers display informative potential to quantify the genetic variability of different groups from Brazilian buffalos.

In 2009, Mishra et al. [7] established the state of the population of Chilika buffalos of the Indian East, using cytogenetic and molecular markers. In this study it was determined that the analyzed population owns 50 chromosomes, bears a resemblance to the typical buffalos of river. Various diversity estimates, viz. observed number of alleles (4.68), effective number of alleles (2.79), and observed (0.487) and expected (0.602) heterozygosity across 25 heterologous microsatellite markers indicated the presence of a moderate level of genetic diversity in Chilika buffaloes, comparable with three other prominent Indian riverine buffalo breeds (Murrah, Nagpuri and Toda) included in this study. Across the four buffalo populations, mean estimates of F-statistics from Jackknifing over loci were significantly different from zero $(p<0.05)$, with FIT (total inbreeding estimate) $=0.315 \pm 0.038$, FIS (withinpopulation inbreeding estimate) $=0.178 \pm 0.038$, and FST (population differentiation) $=0.166 \pm 0.025$. Interbreed analysis reflected Chilika buffaloes to be genetically close to Nagpuri followed by Murrah and Toda buffaloes. Factorial correspondence analysis (FCA) revealed low breed-specific clustering of Chilika and Nagpuri buffaloes. Additionally, the neighbour joining tree structure of mitochondrial DNA D-loop haplotypes indicated clear grouping of the Chilika haplotypes with the riverine buffalo. Thus the cytogenetic, microsatellite and mitochondrial data analyzed in this study classify Chilika buffalo of eastern India to be of the riverine type and not swamp-type buffalo.

Kumar et al. [8] sequenced the mitochondrial D-loop region and cytochrome $b$ gene of 217 and 80 buffalo respectively from eight breeds/locations in northern, north-western, central and southern India and compared its results with published Mediterranean and swamp buffalo sequences. Using these data, river and swamp buffalo were distinguished into two distinct clades. Based upon the existing knowledge of cytogenetic, ecological and phenotypic parameters, molecular data and present-day distribution of the river and swamp buffalo, they suggest that these two types were domesticated independently, and that classification of the river and swamp buffalo as two related subspecies is more appropriate.

In the same way, Abdel-Rahman [9] extracted muscle-DNA from cattle and buffalo to amplify the mitochondrial DNA segment (cytochrome $b$ gene) and the gene encoding species-specific repeat (SSR) region. They used polymerase chain reactionrestriction fragment length polymorphism (PCR-RFLP) and SSR techniques to identify of species origin. Restriction analysis of PCR-RFLP of the mitochondrial cytochrome $b$ segment and SSR analysis showed no differences between cattle and buffalo. Where, the fragment length generated by Alul PCR-RFLP were 190, $169 \mathrm{pb}$ and PCR amplification size of the gene encoding SSR region was $603 \mathrm{bp}$ in both cattle and buffalo. The finding from this study revealed that cattle and buffalo are evolutionary derived from the same ancestor. 
When analyzing genes associated with productive characters, Meignanalakshmi and Mahalinga Nainar [10] used PCR-RFLP analysis of beta-lactoglobulin (blg) gene locus carried out on 110 DNA samples of Murrah buffaloes. A 262 bp fragment enclosing from exon IV to intron IV in b-lg gene was amplified with specific primers. All the 110 DNA samples resulted in 262 bp product on amplification. The PCR products were subjected for digestion with Pstl, EcoRl, HindllI and Haell enzyme. PCR products were not digested by Pstl, EcoRl and Hindlll. PCR products when digested with Haelll enzyme resulted in monomorphic banding pattern in all the samples. Sequencing of PCR products also revealed no polymorphism (GenBank DQ340204). The DNA typing results agreed completely with the milk protein typing of same buffalo milk samples for beta-lactoglobulin by PAGE, which revealed no polymorphism. PCR amplification and RFLP analysis presented in these study was found to be rapid and the author said that could be used as a valuable tool to investigate polymorphism at b-lg locus directly at the DNA level without the milk samples of lactating females. One hundred and ten DNA samples of Murrah buffaloes examined in the present study revealed no polymorphism at b-lg gene locus.

A study developed by Ahmed et al. [11] aimed at detecting genetic polymorphisms in the reproductive candidate genes follicle-stimulating hormone receptor (FSHR), insulin-like growth factor 1 (IGF-1), insulin-like growth factor 1 - receptor (IGF-1R), inhibin beta-A (INHBA), and signal transducer and activator of transcription 5 (STAT5A) and establish their association with calving interval $(\mathrm{Cl})$ as an early predictor of the reproductive efficiency of fertility status. Genomic DNA was extracted from whole blood of unrelated Egyptian buffalo females. The PCR products of investigated genes were subjected to single-strand conformation polymorphism analysis. The results illustrated that the FSHR gene locus showed three polymorphic patterns with $61.4 \%$ for pattern $1,21.4 \%$ for pattern 2 and $17.2 \%$ for pattern 3 . The IGF-1 gene locus had two polymorphic patterns with $84.3 \%$ for pattern 1 and $15.7 \%$ for pattern2. IGF-1R gene locus had four polymorphic patterns with $50 \%$ for pattern 1 , $28.6 \%$ for pattern 2, $15.7 \%$ for pattern 3 and $5.7 \%$ for pattern4. The INHBA gene locus was monomorphic. The STAT5A gene locus had three polymorphic patterns with $91.4 \%$ for pattern $1,4.3 \%$ for pattern 2 and $4.3 \%$ for pattern 3 . Correlations between the phenotypic data and the molecular results of genes studied revealed that pattern 2 of FSHR gene locus recorded the lowest $\mathrm{Cl}$ with prediction of $70 \%$ accuracy for the phenotype of high fertility; IGF-1 gene locus had no impact on fertility; IGF-1R gene locus predicted the phenotype of the high fertility with approximately $83.3 \%$ accuracy for pattern 2; INHBA gene locus had no impact on fertility and pattern 2 of STAT5A gene locus was associated with high fertility, while pattern 3 was associated with low fertility. The combined information of the phenotypic and molecular data could be the most powerful protocol in the improvement of the reproductive efficiency in buffalos.

Also the molecular tools have been used for originating studies of traceability of products from different cattle species. In this sense Abdel-Rahman and Ahmed [12] developed species-specific PCR and PCR-RFLP techniques for the rapid, specific and sensitive identification of buffalo's, cattle's and sheep's milk. DNA from small amount of fresh milk (100 $\mu \mathrm{L})$ was extracted to amplify the gene encoding speciesspecific repeat (SSR) region and the mitochondrial DNA segment (cytochrome-b gene). PCR amplification size of the gene encoding SSR region was $603 \mathrm{bp}$ in both buffalo's and cattle's milk, while in sheep's milk was $374 \mathrm{bp}$. Polymerase chain reaction-restriction fragment length polymorphism (PCR-RFLP) technique was used to discriminate between buffalo's and cattle's milk. Restriction analysis of PCR-RFLP of the mitochondrial cytochrome-b segment (359 bp) analysis showed difference between buffalo and cattle milk. The fragment length generated by Taql PCR-RFLP were 191 and $168 \mathrm{pb}$, whereas no fragments were obtained in cattle's milk for cytochrome-b gene (359 bp). The proposed PCR and PCR-RFLP assays represent a rapid and sensitive method applicable to the detection and authentication of milk species-specific.

In Cuba the molecular characterization of the breed Buffalypso has started recently. Acosta et al. [13] presented a molecular characterization of Cuban water buffalo population, on the basis of 16 bovine-specific microsatellite markers. The mean number of alleles across the 16 loci was 5.44, and the largest number of alleles for locus was 9 for the ETH225 marker and fewer alleles were 2 for the TGLA126 marker. Observed average heterozygosity was $0.46 \pm 0.23$ and expected heterozygosity was $0.54 \pm 0.19$. The observed value of inbreeding coefficient (FIS) was of 0.148 and three loci were with significant reduction of heterozygosity (ETH3, HAUT24 and INRA032). Four loci were not in the Hardy-Weinberg equilibrium with a significant deficit heterozygote (ETH3, CSRM60, HAUT24 and INRA032). The overall polymorphic 
information content value for these markers was 0.495 ; therefore these markers can be used in study of genetic diversity and differentiation of our population with other. The observed value of inbreeding coefficient if is compared with other population suggests to think in a high inbreeding accumulate. The present study on Cuban water buffalo population represents a preliminary effort of molecular characterization in this population.

The examples of applications of the molecular tools in the study of the buffaloes populations are many and all of them will contribute without a doubt, to improve the knowledge of the species and a better genetic handling of the same.

\section{REFERENCES}

[1] Clarke B. The causes of biological diversity. Sci Amer 1975; 233: $50-60$ http://dx.doi.org/10.1038/scientificamerican0875-50

[2] Berovides V, Alfonso A. Los genes en las poblaciones. Ed. Universidad de la Habana, La Habana 1987; p. 277.

[3] Grodzicker T, Williams J, Sharp P, Sambrook J. Physical mapping of temperature sensitive mutations. Cold Spring Harbor Symp Quart Biol 1974; 39: 439-46.

[4] Mullins KB, Faloona FA. Specific synthesis of DNA in vitro via a polymerase-catalysed chain reaction. Methods in Enzymology 1987; 155: 335-50.

http://dx.doi.org/10.1016/0076-6879(87)55023-6

[5] Ferreira ME, Grattapaglia D. Introdução ao uso de marcadores moleculares em análise genética. $2^{\text {nd }}$ ed. EMBRAPA-CENARGEN, Brasília 1996; pp. 121-30.
[6] Albuquerque MMS, Egito AA, Marques JRF, et al. Variabilidade genética em búfalos estimada por marcadores RAPD. Pesq Agropec Bras, Brasília 2006; 41: 623-8.

[7] Mishra BP, Kataria RS, Bulandi SS, et al. Riverine status and genetic structure of Chilika buffalo of eastern India as inferred from cytogenetic and molecular marker-based analysis. J Anim Breed Genet 2009; 126: 69-79. http://dx.doi.org/10.1111/j.1439-0388.2008.00759.x

[8] Kumar S, Nagarajan M, Sandhu J, Kumar N, Behl V, Nishanth G. Mitochondrial DNA analyses of Indian water buffalo support a distinct genetic origin of river and swamp buffalo. Animal Genetics 2007; 38: 227-32. http://dx.doi.org/10.1111/j.1365-2052.2007.01602.x

[9] Abdel-Rahman SM. Evidences reveal that cattle and buffalo evolutionary derived from the same ancestor based on cytogenetic and molecular markers. Biotechnol Animal Husbandry 2006; 22: 1-6. http://dx.doi.org/10.2298/BAH0604001A

[10] Meignanalakshmi S, Mahalinga Nainar A. PCR-RFLP analysis of beta-lactoglobulin gene in Murrah buffaloes Tamilnadu. J Veterinary Animal Sci 2009; 5: 194-7.

[11] Ahmed SS, Abdel aziz KB, Hassan NA, Mabrouk DM. Genetic polymorphism of some genes related to reproductive traits and their association with calving interval in Egyptian buffalo. Genomics Quantitative Genetics 2011; 3: 1-8.

[12] Abdel-Rahman SM, Ahmed MMM. Rapid and sensitive identification of buffalo's, cattle's and sheep's milk using species-specific PCR and PCR-RFLP techniques. Food Control 2007; 18: 1246-9. http://dx.doi.org/10.1016/j.foodcont.2006.08.003

[13] Acosta A, Uffo O, Sanz A, et al. Genetic characterization of Cuban water buffalo population using microsatellite DNA markers. Buffaloes Bulletin 2012; (in press). 